\title{
LIMITY RAWLSOVHO PRÍSTUPU K TEÓRII SPRAVODLIVOSTI V KONCEPCIÁCH EVY F. KITTAYOVEJ A MARTHY C. NUSSBAUMOVEJ
}

LUKÁŠ SIEGEL, Katedra filozofie a aplikovanej filozofie, Filozofická fakulta Univerzity sv. Cyrila a Metoda Trnava, Trnava, SR

SIEGEL, L.: Limits of Rawlsian Approach towards the Theory of Justice in Conceptions of Eva F. Kittay and Martha C. Nussbaum

FILOZOFIA, 74, 2019, No 7, pp. $543-555$

In this article, we will analyze the limits of rationalist contract theories, such as Rawl's theory of justice. The understanding of autonomy and human dignity based on the idea of a rational and self-determining subject that is aware of his interests, rights and can cooperate rationally is not sufficient as a foundation for defining the social rights and specific rights of minorities (persons with disabilities, elderly citizens, or children). Ethics of care outlined by Eva F. Kittay and capability approach described by Martha C. Nussbaum offers a critical reflection on this conventional approach to justice. The focus of submitted reflections is the characterization of a shift from Kant's idea of an autonomous person and a liberal idea of useful mutual reciprocity of individuals (J. Rawls) towards Aristotelian essentialism, which extends the concept of a subject concerning justice. This extension includes ill people, elderly citizens and people with disabilities (E. F. Kittay, M. C. Nussbaum).

Keywords: Rawls, J. - Kittay, E. F. - Nussbaum, C. - Justice - Care - Dependence - Social liberalism - Ethics of care - Capability approach

\section{Úvod}

Súčasnú diskusiu o najvhodnejšej interpretácii spravodlivosti výrazne ovplyvnila Rawlsova teória spravodlivosti. Jeho koncepcia sa stala v oblasti sociálnej filozofie natol'ko závažnou, že sa s ňou museli vyrovnávat' všetky koncepcie sociálnej spravodlivosti. Z hl'adiska filozofickej argumentácie možno Rawlsovo dielo označit' za základ súčasného sociálneho liberalizmu. Rawlsova teória spravodlivosti ako slušnosti špecifikuje férové podmienky racionálnej kooperácie slobodných a rovných bytostí. Týka sa pravidiel distribúcie a redistribúcie tak základných foriem dobra, ako aj slobôd. Vychádza z kantovských pojmov autonómie a l'udskej dôstojnosti, založených na idei racionálneho, sebaurčujúceho subjektu, vedomého si svojich záujmov a práv a schopného racionálne kooperovat', a na liberálnej idei vzájomnej recipročnej užitočnosti. 
Rawlsova teória spravodlivosti čelí rôznym formám kritiky aj z toho dôvodu, že vylučuje mnohé skupiny l'udí, ktoré nespĺňajú kritérium autonómneho a sebaurčujúceho subjektu a sú dlhodobo odkázané na rôzne formy starostlivosti. V štúdii sa zameriame na dve kritiky tohto typu - na etiku starostlivosti Evy Feder Kittayovej a na prístup zameraný na spôsobilosti (capability approach) Marthy Craven Nussbaumovej. Obidve autorky spája posun od Kantovej idey autonómnej osoby a liberálnej idey vzájomnej recipročnej užitočnosti indivíduí (J. Rawls) k aristotelovskému esencializmu, ktorým sa rozširuje pojem subjektu spravodlivosti o chorých, starých a zdravotne postihnutých l'udí. U obidvoch autoriek zásadným východiskom zostáva dôstojnost' života, ale v jej antikantovskom, antiprocedurálnom, pluralitne danom rozmere. Problém odkázanosti na pomoc iných a dlhodobej starostlivosti riešia ako problém sociálnej spravodlivosti. Kittayová vo svojej knihe Práca z lásky (Love's Labor 1999) rozpracovala práve problém odkázanosti na pomoc iných. Poukázala na dôležitost' dlhodobej starostlivosti a problémy, ktorým čelí. Vysvetlila, že idea zranitel'nosti každej l'udskej bytosti a odkázanosti na pomoc iných nepredstavuje závažný problém len pre Rawlsovu teóriu spravodlivosti, ale musí byt' relevantná pre akékol’vek úvahy o spravodlivej spoločnosti. Idea zranitel'nosti každej l'udskej bytosti v podstatnej miere inšpirovala aj Nussbaumovej aristotelovsky motivovaný prístup, zameraný na spôsobilosti (capability approach). ${ }^{1}$ Uznanie zranitel'nosti každého jednotlivca sa v tejto dikcii stáva základným spôsobom konštitúcie nového prístupu k definícii spravodlivosti a l'udských práv.

\section{K východiskám Rawlsovej teórie spravodlivosti}

Rawlsova teória spravodlivosti je modernou verziou racionalistických zmluvných koncepcií. Spoločenskú zmluvu pokladajú za spôsob, ako objasnit' pravidlá spravodlivosti, vznik štátu, jeho inštitúcie a funkcie. Tradícia spoločenskej zmluvy je široko akceptovaná v politike, práve, ekonómii a má vel'mi silný vplyv na to, ako sa l’udia vnímajú navzájom ako politickí aktéri. Myšlienka občana ako nezávislej osoby, ktorá vyjednáva podmienky zmluvy, je každodennou súčast'ou nášho života.

Rawls predpokladá, že k uzavretiu kontraktu prichádza za podmienok, v ktorých nie je nikomu známe jeho budúce postavenie v spoločnosti, a preto pridel'ovanie výhod

\footnotetext{
${ }^{1} \mathrm{~K}$ zakladatel'om prístupu zameraného na spôsobilosti (capability approach) nespochybnitel'ne patrí indický ekonóm a filozof A. Sen. V tejto práci sa nebudeme venovat' Senovej verzii tohto prístupu aj napriek faktu, že Nussbaumová bola výrazne ovplyvnená Senovou koncepciou. Hlavnú pozornost' venujeme Nussbaumovej kritike Rawlsa a reflexii konceptu odkázanosti, ktorý je klúčovým pojmom tak pre Nussbaumovú, ako aj pre Kittayovú, a slúži ako východisko kritiky teórie spravodlivosti J. Rawlsa. K Senovej koncepcii spôsobilostí bližšie pozri Palovičová (2013, 265 - 275).
} 
za závojom nevedomosti prirodzene smeruje k zvýhodňovaniu tých najhoršie postavených členov spoločnosti. Nikto totiž nevie, či to nebude práve on, kto sa ocitne na ich mieste. Závoj nevedomosti podla Rawlsa zaručuje, že systém pravidiel zvolený v tejto situácii bude spravodlivý. Inými slovami, človek ako racionálna bytost', ktorá pozná svoje záujmy a vie ich aj racionálne artikulovat', je ochotný dodržiavat' pravidlá dovtedy, pokým mu prinášajú úžitok. Spravodlivost' predstavuje cnost' každej spoločnosti, ktorá je základom práv každého človeka (Rawls 1995, 17 - 19). Práve stanovenie určitých základných práv a povinností je relevantným aspektom pri budovaní akejkol'vek spoločenskej štruktúry. Základné podmienky spravodlivosti možno podl’a Rawlsa stanovit' za závojom nevedomosti. Ide o pôvodnú pozíciu, v ktorej nikto v spoločnosti nepozná svoje miesto ani sociálne postavenie, nepozná svoje schopnosti a vlastnosti. V týchto podmienkach si volíme základné princípy spravodlivosti (Rawls 1995, 21).

Rawls predpokladá, že nikto si nezvolí podmienky, ktoré by uprednostňovali jeho špecifickú situáciu (Rawls 1995, 22). Inými slovami, ak nikto nepozná svoju situáciu, tak je nepravdepodobné, že by si niekto volil podmienky, ktoré by uprednostňovali niečo, čo nepozná. Rawlsova teória spravodlivosti predpokladá, že „ludia v pôvodnom stave sú rozumní. Pri vol'be princípov sa každý snaží najlepšie, ako vie, presadzovat' svoje záujmy“ (Rawls 1995, 95). Ide o ideál osôb, ktoré sa „môžu zapojit’ do sociálnej spolupráce počas celého svojho života, potom zároveň môžu prevziat' zodpovednost' za svoje ciele; ide teda o to, že môžu prispôsobit' svoje ciele takým spôsobom, aby ich mohli dosiahnut' prostriedkami, o ktorých môžu rozumne predpokladat', že ich získajú ako odmenu za svoj vlastný predpokladaný prínos“ (Rawls 1997, 28). Ďalej sa občania snažia rozumne (respektíve racionálne) uvažovat' o ciel'och, ktoré chcú dosiahnut'. Rawls upevňuje toto tvrdenie, pretože uvádza, že l’udia sú racionálni, hoci často nepoznajú ciele, ktoré chcú dosiahnut'. Vedia však, že sa tieto ciele budú usilovat' dosiahnut' inteligentne (Rawls 1997, 41). Za takýchto podmienok možno určit princípy spravodlivosti, ktoré by si podl’a jeho názoru l'udia zvolili za závojom nevedomosti.

Prvý princíp spravodlivosti hovorí: „Každá osoba musí mat’ rovnaké právo na čo najširší systém základných slobôd, ktoré sú zlučitel'né s obdobnými slobodami pre iných l'udí (Rawls 1995, 48). Podl'a druhého princípu „sociálne a ekonomické nerovnosti majú byt' upravené tak: (a) aby sa u oboch dalo rozumne očakávat', že budú na prospech kohokol'vek; a (b) aby boli späté s pozíciami a úradmi prístupnými pre všetkých" (Rawls 1995, 48). Prvý princíp je pomerne jasný, problém môže predstavovat' druhý princíp. Otázkou je, akú skupinu Rawls rozumie pod pojmom „,najmenej zvýhodnenou“, pretože v spoločnosti sú rôzne skupiny l’udí, ktoré možno zaradit' do tejto kategórie. Rawls pokladá za najviac znevýhodnených tých, ktorí sú v t’ažkej ekonomickej situácii. Iné formy znevýhodnenia nie sú v Rawlsovom procedurálnom ja- 
zyku zohl'adnené, podobne ako ani pluralita podôb dôstojného či nedôstojného života, ktorá z nich vyplýva.

Zásadný problém Rawlsovho ${ }^{2}$ prístupu k spravodlivosti tkvie v tom, že princípy spravodlivosti špecifikujú férové podmienky racionálnej kooperácie slobodných a rovných bytostí, vedomých si svojich záujmov a schopných ich racionálne artikulovat', pričom sa zabúda na tých, ktorí na tejto fiktívnej zmluve neparticipujú, teda na seniorov, l'udí so zdravotným postihnutím a na sociálne vylúčených l’udí. Na tento nedostatok liberalizmu upozorňuje mnoho myslitel'ov nielen priamo komunitaristických, ale aj liberálnych. Jednou zo súčasných analýz Rawlsa je stat' z diela Disability and Political Theory (2016), v ktorej autorka Stacy Clifford Simplican prichádza so zásadnou kritikou Rawlsovho prístupu k osobám so zdravotným postihnutím. Tvrdí, že Rawls vníma problematiku zdravotného postihnutia (respektíve osôb odkázaných na starostlivost') ako niečo vzdialené jeho teórii (Simplican 2016, 83). Poukazuje aj na Rawlsovu tendenciu citovat' a parafrázovat' autorov, ktorí pokladajú zdravotné postihnutie za medicínsky problém, a nie za problém sociálny či spoločenský (Simplican 2016, 88 - 90). Rawlsov výber autorov a expertov môže odhalit' jeho vlastný pohl'ad na problematiku zdravotného postihnutia. Práve prístup, ktorý pozorujeme v našej analýze Rawlsa, tkvie v odsúvaní problému odkázanosti a starostlivosti. Pritom ide o jasnú súčast' života každého človeka, ktorá patrí k vývojovým fázam života. Každý z nás je ako diet’a odkázaný na starostlivost' rodičov, môžeme ochoriet', alebo sa narodit' so zdravotným postihnutím, či neskôr starnút'.

\section{Kritika Rawlsovej teórie spravodlivosti v etike starostlivosti Evy Feder Kittayovej} Americká predstavitel'ka mladšej generácie etičiek starostlivosti ${ }^{3}$ Eva Feder Kittayová prináša svojou interpretáciou starostlivosti nové podnety do diskusie o spravodlivosti. Starostlivost' o odkázaných sa v modernej tradícii myslenia zvyčajne chápe ako práca z lásky, teda ako niečo, čo primárne musia zabezpečovat' rodičia, dospelé deti či príbuzní z lásky, súcitu a oddanosti k tým, ktorí sú závislí od ich pomoci. Napriek skutočnosti, že potreba starostlivosti je v rôznych obdobiach l'udského života nesporná, relatívne malá pozornost' sa venuje otázke, čo táto skutočnost' znamená pre politickú filozofiu. Tieto otázky boli nastolené až v etike starostlivosti, ktorá upozornila na problém odkázanosti $\mathrm{v}$ živote každého človeka. ${ }^{4} \mathrm{Na}$ rozdiel od starších verzií etiky

\footnotetext{
${ }^{2}$ Rawls sa venuje svojej teórii aj v diele Spravodlivost’ ako férovost' (2007), kde taktiež rozvíja koncept spravodlivosti, avšak ani tu nevenuje problematike odkázanosti patričnú pozornost'.

${ }^{3}$ Pre koncept etiky starostlivosti pozri aj Urban $(2015,119-129)$.

${ }^{4}$ Jednou z prvých prác venovaných etike starostlivosti bola práca Milton Mayeroff $O$ starostlivosti (1971), ale vznik etiky starostlivosti ako samostatnej morálnej teórie sa spája s prácami psychologičky Carol Gilliganovej a filozofky Nel Noddingsovej v polovici osemdesiatych rokov dvadsiateho
} 
starostlivosti Kittayová neformuluje svoju teóriu ako alternatívu k liberálnym teóriám spravodlivosti a l’udských práv. Práve naopak, riešenie odkázanosti na pomoc iných a zabezpečenie dlhodobej starostlivosti pokladá za legitímnu súčast' liberálnych úvah o spravodlivosti. Vydanie Kittayovej knihy ${ }^{5}$ Práca z lásky (1999) predstavovalo významnú udalost' v politickej a morálnej filozofii z viacerých dôvodov. Po prvé, problém zdravotného postihnutia postavila ako relevantnú súčast' morálnej a politickej filozofie $\mathrm{v}$ tom zmysle, že ide o zásadné otázky, s ktorými sa budú musiet' vyrovnat' teórie spravodlivosti. Po druhé, sformulovala (predtým bol min. čas)niektoré presvedčivé argumenty pre kritiku zmluvných teórií spravodlivosti. ${ }^{6}$ Autorka tvrdí, že ak chceme formulovat' adekvátne návrhy na spravodlivý prístup k l'ud’om odkázaným na starostlivost' a k tým, ktorí sa o nich starajú, žiada si to prekonat' obraz občianstva zakotveného $\mathrm{v}$ dominantnej tradícii spoločenskej zmluvy, ktorá je jadrom teoretizovania o spoločnosti.

Kittayová výstižne artikuluje zásadný problém Rawlsovej teórie, pričom poukazuje na rozhodujúcu ideu racionálneho, sebaurčujúceho subjektu a definíciu reciprocity v Rawlsovej teórii spravodlivosti. Kittayová, podobne ako Nussbaumová, namieta, že pre určenie najmenej zvýhodnenej skupiny nepostačuje ekonomické kritérium, pretože do tejto premeny abstraktných prostriedkov (výška príjmu) na aktuálny typ života, ktorý l'udia žijú, vstupujú rôzne typy náhodných faktorov, akými sú vek, zdravotné postihnutie alebo choroba. Jedným z takýchto konverzných faktorov je odkázanost' na pomoc iného človeka, ktorá je prítomná v živote každého z nás. Môžeme ju vnímat' v detstve, počas choroby, postihnutia, ba dokonca aj v starobe (Kittay 1999, 29). Každý z nás

storočia. Obidve autorky potvrdili význam „hlasu starostlivosti“ ako legitímnej alternatívy k liberálnym teóriám l’udských práv.

${ }^{5}$ Kittayovej pozícia neprechádza zásadnými zmenami ani v novších článkoch a štúdiách, ktoré sa venujú problematike odkázanosti. Zastáva pozíciu, ktorá berie do úvahy postavenie a kvalitu života l'udí odkázaných na starostlivost'. Uvádza, že tá je stále nedostačujúca, a preto je nutné vytvárat' opatrenia, ktoré budú dostatočne reflektovat' potreby tejto skupiny. V štúdii The Ethics of Care, Dependence, and Disability Kittayová uvádza, že v súčasnosti stále bojuje táto skupina s diskrimináciou v rôznych spoločenských sférach (Kittay 2011, 49). Upozorn̆uje na vzt’ah medzi opatrovatel’om a osobou odkázanou na starostlivost', pretože obaja do značnej miery ovplyvňujú život toho druhého (Kittay 2011, 50). Za najpodstatnejší prínos štúdie sa dá pokladat’ jej argumentácia, ktorá odkázanost' a starostlivost' radí $\mathrm{k}$ bežným súčastiam l'udskej existencie. Autorka tvrdí, že pre spoločnost' by bolo lepšie, keby uznala odkázanost' a všetky faktory, ktoré k nej prináležia, za bežnú súčast' života a nastavila opatrenia tak, aby reflektovali tento fenomén v dostatočnej miere, ktorá zabezpečí dôstojný a kvalitný život (Kittay 2011, 53 - 55).

${ }^{6}$ Okrem iného jej teoretická iniciatíva ponúkla silné argumenty pre zmeny v americkej legislatíve a verejnej politike, čím dokázala, že filozofia môže ovplyvnit' konkrétne politické rozhodnutia. Práca púta pozornost' aj tým, že je opisom reálneho života autorkinej dcéry, ktorej život s postihnutím je neoddelitel’nou argumentačnou bázou teoretických úvah a núti k premýšl'aniu o živote l’udí so zdravotným postihnutím. Práca Evy Kittayovej podnecuje závažné otázky o úlohe reálnej inšpirácie $\mathrm{v}$ politickej a morálnej filozofii. 
potrebuje podporu a pomoc bud' blízkej osoby, alebo určitú formu opatrovníctva. Nemôžeme to vnímat' ako nevšednú životnú situáciu, pretože je bežnou súčast'ou nášho života (Kittay 1999, 29). ${ }^{7}$ Táto forma podpory by mala byt' chápaná ako práca, pretože ten, kto poskytuje starostlivost', musí vynaložit' nadmerné úsilie, aby zabezpečil správnu starostlivost' a prostredie pre odkázaného (Kittay 1999, 30). Fenomén odkázanosti je pre Kittayovú natol'ko rozhodujúci, že by mal zastávat' kl’účovú pozíciu pri analýze spravodlivej spoločnosti.

Kittayová odoláva tendencii idealizovat' starostlivost' výlučne ako cit alebo dispozičnú zvláštnost' a odhal'uje celú šŕrku činností, ktoré so sebou starostlivost' prináša vo všetkých sférach života (starostlivost' o deti, zdravotne postihnutých členov rodiny, rodičov v starobe, $\mathrm{v}$ období choroby a pod.). Identifikuje tri základné znaky tejto práce. Po prvé, je to zodpovednost' za niekoho, kto je v mnohých smeroch bez opatrovatel'a bezmocný. Z toho vyplýva, že starostlivost' je morálnou povinnost’ou, ktorá presahuje limity iných prác v domácnosti. Po druhé, pretože opatrovatel'ská práca vyžaduje citlivost' $\mathrm{k}$ potrebám toho druhého, často je vytušenie potrieb opatrovaného $\mathrm{v}$ podstatnej miere zviazané $\mathrm{s}$ istou mierou emocionálnej väzby k opatrovanému. Kittayová uvádza, že bez ohl’adu na to, či „sme tí, ktorí starostlivost' potrebujú, alebo chceme nájst' niekoho, kto poskytne starostlivost' za nás, potrebujeme hlavne niekoho, kto sa stará“ (Kittay 1999, 130). Navyše vzhl'adom na to, že „opatrovatel'ská práca je skôr nepresne vymedzená (functionally diffuse) ako špecificky určená (functionally specific), opatrovatel' nemá fixne daný zoznam úloh, ale vyžaduje sa od neho, aby zabezpečil individuálnu pohodu a zaručil uspokojenie rozmanitých potrieb opatrovaného. Takáto zodpovednost' často neberie do úvahy potreby opatrovatel'a. Po tretie, povinnost' starostlivosti v rodine je často v konflikte s požiadavkami zamestnania na trhu práce“" (Kittay 1999, 130).

Kittayová dáva do pozornosti nielen potreby odkázanej osoby vzhl'adom na starostlivost', ale aj nezastupitel'nú funkciu opatrovatel'a, respektíve poskytovatel'a starostlivosti, pretože táto pozícia nie je dostatočne spoločensky uznaná a opatrovatel' často vykonáva dané činnosti na úkor svojho vlastného života. Primárne ide v takýchto situáciách o členov rodiny, ktorí poskytujú starostlivost' svojmu blízkemu. Obidve tieto skupiny (opatrovatelia a tí, ktorí starostlivost' prijímajú) sú nezanedbatel'nou skupinou v spoločnosti, a preto by mali byt' zohl'adnení aj pri tvorbe spoločenských pravidiel a hodnôt.

\footnotetext{
${ }^{7}$ Kittayová píše: „Naša odkázanost' nie je potom dôsledkom mimoriadnych okolností. Keby sme na ňu nazerali týmto spôsobom, znížime relevantnost' l’udskej prepojenosti. Nielen pre účely prežitia, ale aj pre rozvoj kultúry samotnej“ (Kittay 1999, 29). Treba upriamit’ pozornost' na fakt, že Kittayová prepája rozvoj kultúry a spoločnosti s problematikou odkázanosti.
} 
Podl'a Kittayovej musí spravodlivá spoločnost' zahíňat’ aj skupiny odkázané na starostlivost', čiže osoby so zdravotným postihnutím, deti alebo starších občanov a rôznych iných l'udí (Kittay 1999, 75 - 76). Rawlsovi vyčíta, že do svojej koncepcie spravodlivosti nezakomponoval problém odkázanosti ako klúčcov́ problém sociálnej spravodlivosti ${ }^{8}$ (Kittay 1999, 77). Dodáva, že Rawls určite neodmieta naše povinnosti voči l'ud’om, ktorí nezapadajú do jeho teórie. Vychádza však z predpokladu, že ciel'om politickej filozofie je vypracovat' ucelenú teóriu spravodlivosti pre občanov, ktorí sa považujú počas celého svojho života za slobodných a plne kooperujúcich členov spoločnosti. Aj Rawls odporúča špeciálnu korekciu v prípade špeciálnych potrieb. Základným problémom týchto odporúčaní je, že nie sú súčast'ou jeho princípov spravodlivosti: nepatria medzi „primárne formy dobra“, a preto nie sú relevantné ani pre ich ústavné zakotvenie (Kittay 1999, 86). Podl'a Kittayovej ide o zásadný problém mnohých racionalistických zmluvných koncepcií, ktoré nereflektujú reálny stav, ale zameriavajú sa na ideálny svet. $Z$ jej hl'adiska je pri zostavovaní akejkol'vek koncepcie spravodlivosti nevyhnutné zohl’adňovat' reálne situácie a skutočný stav vecí samotných.

Ďalšou výhradou Kittayovej voči Rawlsovej teórii spravodlivosti je idealizácia občana. Rawls vníma všetkých l'udí ako úplne sebestačných a participujúcich členov spoločnosti (Kittay 1999, 88 - 89). Kittayová namieta, že adekvátna koncepcia spravodlivosti musí nevyhnutne brat' do úvahy aj slabost' a krehkost' l'udského života. Idealizácia občana má totiž závažné praktické konzekvencie. Kittayová uvádza: „Ak je odkázanost' uznaná ako jedna zo základných podmienok spravodlivosti, potom odkázaný človek je zastúpený ako plne fungujúci občan počas obdobia odkázanosti“ (Kittay 1999, 89). Podl'a Kittayovej treba klást' dôraz na fenomén odkázanosti už pri určení primárnych foriem dobra, ktoré sú relevantné pre ústavné zakotvenie. Kittayová poukazuje na d’alší dôležitý aspekt starostlivosti o odkázaných, ktorým je pozícia opatrovatel’ov v spoločnosti. Táto početná skupina l’udí je taktiež prehliadaná. Práca opatrovatel'ov je podl'a nej vel'mi špecifická, pretože „skupina tých, ktorí reprezentujú opatrovatel'ov, vie, že nemôžu mysliet' len na svoje záujmy, ale musia zvážit' aj záujmy odkázaného“ (Kittay 1999, 90). Rawlsovu teóriu spravodlivosti žiada doplnit” o princíp sociálnej zodpovednosti za dlhodobú starostlivost', ktorý znie: „Každému podl'a jeho potrieb, každému podl’a jeho spôsobilosti starat' sa o seba a takú podporu zo strany sociálnych inštitúcií $\mathrm{k}$ sprístupneniu zdrojov a príležitosti, aby bolo o všetkých adekvátne postarané" (Kittay 1999, 113). Inými slovami, spravodlivost’ pre

\footnotetext{
${ }^{8}$ Kittayová pripomína, že nielen v Teórii spravodlivosti, ale ani neskôr $v$ Politickom liberalizme sa nevenuje tomuto problému pozornost'. Citujeme: „Rawls nepovažuje tieto námietky za kl'účové pre jeho politickú teóriu. Obzvlášt' potom, ako vylepšuje zámer svojej teórie v práci Politický liberalizmus, sú tieto námietky úplne vypustené“ (Kittay 1999, 77).
} 
opatrovatel'ov a opatrovaných sa dosiahne len prostredníctvom takých koncepčných a inštitucionálnych reforiem, v rámci ktorých bude starostlivost' patrit' medzi základné formy dobra, ktoré majú ústavné zakotvenie. Takáto úprava vyžaduje uznat', že odkázanost' na pomoc iných v určitých obdobiach života je podstatnou zložkou l'udského života, a preto patrí medzi tie formy dobra, ktoré prináležia všetkým. Z faktu, že všetci sme „diet'at'om niekoho“ (some mother's child), čiže existujeme v prepletených vzt'ahoch závislosti, vyplýva, že starostlivost' patrí medzi kl’účové požiadavky v politickej teórii (Kittay 1999, $23-24){ }^{9}$

\section{Nussbaumovej kritika Rawlsovej teórie spravodlivosti}

Limity Rawlsovej teórie spravodlivosti sú predmetom úvah aj Marthy C. Nussbaumovej, ktorá je popri Amartyovi Senovi v súčasnosti azda najvplyvnejšou autorkou filozofických teórií spravodlivosti. Rovnako ako u Rawlsa aj u nej zásadným východiskom zostáva dôstojnost’ života, ale v jej antikantovskom, antiprocedurálnom, pluralitne danom rozmere. Kl'účovým pojmom v jej koncepcii spravodlivosti je pojem spôsobilostí (capabilities), ktorý do filozofie zaviedol nositel' Nobelovej ceny za ekonómiu a politický filozof Amartya Sen. ${ }^{10}$ Tento koncept predstavuje istú formu slobody, ked' si jedinec volí, čo chce dosiahnut' a čo pokladá za hodnotné. ${ }^{11}$ Nussbaumová vo svojej perspektíve zohl'adňujúcej spôsobilosti používa aj aristotelovský termín životného zdaru (flourishing), ktorý tkvie „,v súbore základných l'udských nárokov, ktoré vytvárajú predpoklad pre rozličné spôsoby života; nárokov, ktoré sú obsiahnuté v idei l'udskej dôstojnosti“ (Nussbaum 2007, 182). Dôrazom na pojem spôsobilosti, resp. životný zdar, rozširuje pojem subjektu spravodlivosti v definícii dôstojného života o chorých, starých, zdravotne (mentálne) postihnutých l'udí, ale tiež o zvieratá.

Za slabé miesto Rawlsovej teórie spravodlivosti Nussbaumová pokladá problém spravodlivosti vo vzt'ahu k zdravotne postihnutým l'ud'om. Uvádza, že osoby so

\footnotetext{
${ }^{9}$ Kittayová na základe svojej teórie navrhuje konkrétne opatrenia v oblasti americkej sociálnej politiky. Napríklad podporuje obnovu pomoci rodinám s nezaopatrenými det’mi, program na podporu chudobných rodín, obnovu nemocenského zákona z roku 1993, nárok na dovolenku z dôvodu starostlivosti či choroby atd'. K podobným záverom ako Kittayová prichádzajú aj českí autori A. Koubová a P. Urban, ktorí píšu: „V spoločnosti, ktorá si cení ako najvyššie hodnoty sebestačnost', nezávislost' a výkonnost', je ale starostlivost' chápaná ako zát'až a ,nutné zlo ““ (Koubová a Urban 2018, 719).

${ }^{10}$ Nussbaumová aplikovala Senov prístup na špecifické skupiny - osoby so zdravotným postihnutím, národy, zvieratá. V stati sa obmedzíme len na problém spravodlivosti vo vzt’ahu k zdravotne postihnutým l'ud'om. Vzhl'adom na rozsah state mimo našej pozornosti ostáva problém spravodlivosti, ktorý vzniká medzi bohatými a chudobnými národmi a napokon problém spravodlivosti vo vzt’ahu k zvieratám. Spomínané problémy zahŕňajú rôzne asymetrie moci, týkajú sa bytostí, ktoré disponujú limitovanými schopnost’ami.

${ }^{11}$ Bližšie pozri Palovičová $(2011,833$ - 844).
} 
zdravotným postihnutím sú stále členmi spoločnosti, teda občanmi, a mali by sme im umožnit' prežit' produktívny život (Nussbaum 2007, 98). Rawlsovej teórii vyčíta, že dostatočne nerieši rovnost' práv osôb so zdravotným postihnutím. Nussbaumová obhajuje prístup zameraný na rozmanitost' schopností človeka, ktorý v konečnom dôsledku chápe osoby so zdravotným postihnutím ako plnoprávnych a rovných občanov (Nussbaum 2007, 98 - 99). Výnimkou nemôžu byt' ani extrémne postihnutia, ktoré sú na okraji l’udskej skúsenosti. Znamená to, že okrem zdravotnej starostlivosti a opatrovníctva zabezpečuje aj otázku vzdelania takým spôsobom, akým si dané postihnutie vyžaduje, a l'ud’om, ktorí sa o týchto l'udí starajú, poskytuje uznanie, l'udskú aj finančnú podporu, príležitost' na zamestnanie a možnost' aktívnej účasti na spoločensko-politickom živote. Preto je nutné, aby spoločnost' uznala ich prácu za plnohodnotnú. ${ }^{12}$ Dodáva, že „starostlivost' o deti, starších l’udí a l'udí s mentálnym a telesným postihnutím je hlavnou čast'ou práce, ktorá má byt' vykonaná v akejkol'vek spoločnosti a vo väčšine spoločnosti je prameňom obrovskej nespravodlivosti. Preto sa akákol'vek teória spravodlivosti musí zamysliet' nad problémom už od začiatku, v návrhu základnej inštitucionálnej štruktúry a hlavne $\mathrm{v}$ rámci primárnych foriem dobra" (Nussbaum 2007, 127).

Z tohto uhla pohl'adu Nussbaumová odmieta Rawlsov predpoklad, že ciel'om politickej filozofie je vypracovat' ucelenú teóriu spravodlivosti pre občanov, ktorí sa považujú počas celého svojho života za slobodných a rovných l'udí a za plne kooperujúcich členov spoločnosti. Až potom sa pokúšat' zahrnút' do nej „extrémnejšie prípady“ (Nussbaum 2007, 16, 108 - 109). Racionalistickým typom spoločenských zmlúv vyčíta, že vychádzajú z predpokladov rovnocenných, nezávislých, slobodných a racionálnych bytostí, ktoré vedia o vlastných záujmoch a právach a vedia ich aj artikulovat', čím vynechávajú z kontraktu bytosti, ktoré nie sú v stave artikulovat' svoje záujmy, alebo musia získavat' schopnosti a príležitosti žit' dôstojný život za skrytú cenu. Tým racionalistické zmluvné teórie odsúvajú l’udí s mentálnym postihnutím do úzadia a inštitúcie, ktoré vytvárajú, nezohl’adňujú ich špecifické potreby, ani ich opatrovatel'ov. Rawls vidí problém v tom, že l'udskú dôstojnost' zakotvil $\mathrm{v}$ racionalite človeka, nie $\mathrm{v}$ potrebách l'udskej osoby zdiel’anej aj s inými živočíchmi (Nussbaum 2007, 159). Nussbaumová požaduje znovu premysliet' východiskovú pozíciu, v ktorej sa vyberajú princípy spravodlivosti tak, že odmietneme určité predpoklady, na ktorých stojí spoločenská zmluva, reformulujeme ideu ludskej dôstojnosti, aby každej l'udskej bytosti boli poskytnuté rozsiahle primárne dobrá, ktoré zodpovedajú idei spravodlivosti (Nussbaum 2007, 175 - 177). Pre Nussbaumovú

\footnotetext{
${ }^{12}$ V kontexte starostlivosti o zdravotne znevýhodnených l'udí Nussbaumová otvára aj otázku rodovej rovnosti z hladiska spravodlivosti.
} 
je dôležitá diverzita l'udských bytostí, pretože človek nachádza uspokojenie v rôznych formách sebarealizácie, ako o tom svedčí široký koncept primárnych dobier.

Nussbaumová kritizuje aj ideu vzájomnej recipročnej užitočnosti indivíduí ako predpoklad spoločenskej zmluvy (Nussbaum 2007, 98). ${ }^{13}$ Rawls definuje reciprocitu ako vzt’ah medzi rovnocennými občanmi. V sociálnom zmysle slova ide o zamlčaný predpoklad neplnohodnotnej existencie l'udí so zdravotným hendikepom v zmysle ich neproduktívnosti a nereciprocity vzhl'adom na spoločnost' (Nussbaum 2007, 98). Nussbaumová ukazuje, že vytvorením vhodných podmienok im umožníme stat' sa plnohodnotnými členmi spoločnosti (Nussbaum 2007, 105). Z Nussbaumovej kritiky vyplýva, že produktivita nemôže rozhodovat' o tom, či človeku priznáme jeho l'udské práva. Produktivita nie je a nemala by byt' hlavným ciel’om sociálneho života, nemali by sme získavat' rešpekt len na základe toho, že budeme produktívni (Nussbaum 2007, 121, 125, 135). Nussbaumová v texte naznačuje tieto tézy viackrát, pretože $\mathrm{v}$ živote nemôžeme považovat' len produktívny stav za „normálny“.

Poukázaním na hranice l'udskej racionality a vzájomnej recipročnej užitočnosti indivíduí Nussbaumová nastoluje problém spravodlivosti inak - ako otázku dôstojného života bytostí, ktoré nie sú v stave racionálne kooperovat' či byt' si navzájom recipročne užitočné. V rámci Nussbaumovej koncepcie jednotlivec nemôže mat' spôsobilosti bez práva. Ilustruje to na príklade jednotlivcov postihnutých autizmom, ktorí by bez rozsiahleho špecializovaného vzdelávania, financovaného z verejných zdrojov, neboli nikdy schopní stat' sa členmi spoločnosti. Inak vyjadrené, otázka vzdelania či zabezpečenia starostlivosti nie je prejavom dobrej vôle či ústretovosti zo strany spoločnosti, ale realizáciou práva týchto l’udí na vzdelanie, starostlivost', základy sebaúcty a d’alšie práva vyplývajúce z rešpektovania ich špecifických potrieb. Za kl'účový faktor z hl'adiska realizácie práv l'udí so špecifickými potrebami pokladá začlenenie detí do vzdelávacieho procesu, pretože spravodlivá spoločnost' by podl'a nej mala „podporit' ich zdravie, vzdelávanie a plnú participáciu v sociálnom, ale aj v spoločenskom živote“ (Nussbaum 2007, 100). Spoločnost' zohráva u l’udí so špecifickými potrebami dôležitú úlohu, pretože vytvára podmienky, v ktorých môžu realizovat' svoj život a životné rozhodnutia.

Z Nussbaumovej úvah vyplýva, že „nie je len jeden typ životného zdaru“ (Nussbaum 2007, 182). Za kl'účové považuje dohodnút' sa na určitom zozname základných ústavných nárokov, ktoré budú podporovat' rozličné spôsoby života. Tieto

\footnotetext{
${ }^{13}$ Nussbaumová píše: „L’udia s mentálnym postihnutím nepatria medzi tých, na ktorých sa vzt’ahuje princíp reciprocity a pre ktorých sú formované základné spoločenské inštitúcie “(Nussbaum 2007, 98).
} 
nároky budú spadat' pod ideu l'udskej dôstojnosti (Nussbaum 2007, 182). ${ }^{14}$ Určuje desat' základných l’udských spôsobilostí, ktoré sú podl'a nej kl'účové pre každú spoločnost'. Patria k nim: šanca prežit' normálnu dížku života, zdravie, telesná integrita, možnost' využívat' svoje zmysly, možnost' prejavovat' emócie a citovo sa rozvíjat' bez strachu, úzkosti, traumatizujúcich udalostí či prehliadania a ignorovania, možnost' uplatňovat' praktický rozum vo význame realizácie individuálnych životných plánov; afiliácie k druhým osobám (prežívanie vzt'ahov a prejavovanie záujmu o druhých); hry v zmysle možnosti tešit' sa, hrat' sa a pod.; kontrola nad vlastným politickým aj materiálnym prostredím (Nussbaum 2007, 76 78). Tento súbor by mali rešpektovat’ a realizovat' vlády všetkých národov „ako minimum toho, čo vyžaduje rešpektovanie l'udskej dôstojnosti““ (Nussbaum 2007, 70). Spôsobilosti sú navzájom nezamenitel'né, to znamená, že nedostatok jednej nemôže byt' nahradený inou spôsobilost'ou a občania majú právo na všetky spôsobilosti. Prepad pod hraničnú úroveň spôsobilostí pokladá Nussbaumová za zlyhanie spravodlivosti. Nejde len o kompenzáciu zdravotného postihnutia prostredníctvom peňažných príspevkov, ale úlohou verejnej politiky je plná inklúzia l'udí so zdravotným postihnutím do spoločnosti. Treba dodat', že Nussbaumová nepokladá tento zoznam spôsobilostí za uzavretý. Je otvorený zmenám a pripomienkam, pretože žiadny koncept nemôže hned' obsiahnut' všetky aspekty l'udského života. V novšej štúdii Capabilitie, Entitlements, Rights: Supplementation and Critique (2011) Nussbaumová zostáva verná svojim primárnym argumentom a presvedčeniam. Uvádza, že prístup zameraný na spôsobilosti reflektuje dokonca aj problémy, ktoré nedokáže obsiahnut' ani koncept l'udských práv (Nussbaumová 2011, 24). Spôsobilosti považuje za predpolitické, pretože sa viažu na l’udskú existenciu ako takú (Nussbaumová 2011, 25). Dodáva, že jej desat' spôsobilostí je odvodených od základných l'udských nárokov, ktoré by sa mala snažit' zabezpečit' každá vláda (Nussbaumová 2011,27). Nussbaumová je aj vo svojich novších štúdiách verná argumentom, ktoré konštruktívne prezentovala v primárnom diele Frontiers of justice: disability, nationality, species membership.

Prístup zameraný na spôsobilosti nie je politickou doktrínou, nie je ani komprehenzívnou morálnou doktrínou. Jeho ciel'om je určit podmienky l'udsky dôstojného života pre každého človeka (Nussbaum, 2007, 155). Zarad'uje sa medzi liberálne teórie spravodlivosti, nakol'ko predmetom spravodlivosti sú individuálne práva a slobody: právo na vzdelanie, sloboda výberu, sloboda príležitostí, šanca

\footnotetext{
${ }^{14}$ Nussbaumová doslova píše: „Zoznam nie je jednotný preto, že by boli idey občanov o životnom zdare jednotné, ale preto, lebo je rozumné dohodnút' sa na jednotných ústavných nárokoch, ktoré budú poskytovat' základ pre rôzne spôsoby života. Na nárokoch, ktoré sa zdajú byt' súčast'ou myšlienky l'udskej dôstojnosti““ (Nussbaum 2007, 182).
} 
formovat' vlastný plán života atd'. (Nussbaum, 2007, 217). Poukazuje však na nedostatočnost' tradovaných pojmov individuálnej autonómie, l'udskej dôstojnosti, ktoré vychádzajú z tradície Kantovho ideového dedičstva.

\section{Záver}

V štúdii sme analyzovali limity procedurálnych teórií spravodlivosti so zretel'om na schopnosti či príležitosti žit' dôstojný život v prípade bytostí, ktoré nie sú schopné artikulovat' svoje záujmy. Ukázali sme, že chápanie autonómie a l'udskej dôstojnosti, ktoré je založené na idei racionálneho, sebaurčujúceho subjektu, vedomého si svojich záujmov a práv a schopného racionálne kooperovat', nepostačuje ako základ pre definovanie špecifických práv menšín (osôb so zdravotným postihnutím, seniorov, detí). Protinávrh $\mathrm{k}$ takémuto tradičnému prístupu spravodlivosti nachádzame $\mathrm{v}$ etike starostlivosti Evy F. Kittayovej a v prístupe zameranom na spôsobilosti (capability approach) Marthy C. Nussbaumovej, ktoré zohl'adňujú preferencie aj hendikepovaných aktérov. Miera slobody či spôsobilostí poskytuje viac informácií o reálnych príležitostiach a možnostiach jednotlivca robit' slobodné rozhodnutia a umožňuje určit' nerovnosti spôsobené sociálnou štruktúrou, ktorá znevýhodňuje, marginalizuje či diskriminuje určité skupiny. Zdravotné postihnutie sa tu chápe ako jeden $\mathrm{z}$ aspektov l'udskej diverzity, ktoré nie je druhotnou komplikáciou, ktorú by bolo možné ignorovat' či brat' do úvahy neskôr. Je to fundamentálny aspekt našich úvah o rovnosti a spravodlivosti. Rawlsova koncepcia liberalizmu je dobrým základom, ktorú etablovalo mnoho štátov sveta, avšak nedostatočne reflektuje napríklad potreby spomínaných skupín. Preto sme sa v našej analýze zamerali na kritiku a obohatenie Rawlsovej koncepcie o dva prístupy, ktoré môžeme považovat' za kl'účové pre budúce uvažovanie o dobrej a spravodlivej spoločnosti.

\section{Literatúra}

KITTAY, F. E. (1999): Love's Labor: Essays on Women, Equality, and Dependency. New YorkLondon: Routledge.

KITTAY, F. E. (2011): The Ethics of Care, Dependence, and Disability. Ratio Juris, 24 (1), 49 - 58. [https://doi.org/10.1111/j.1467-9337.2010.00473.x]

KOUBOVÁ, A., URBAN, P. (2018): Vztahové pojetí morální subjektivity mezi etikou péče a teorií hry Donalda Winnicotta. Filozofia, 73 (9), 717 - 730.

MAYEROFF, M. (1971): On Caring. New York: Harper \& Row Publishers.

NUSSBAUM, C. M. (2007): Frontiers of justice: disability, nationality, species membership. London: The Belknap Press of Harvard University Press.

NUSSBAUM, C. M. (2011): Capabilities, Entitlements, Rights: Supplementation and Critique. Journal of Human Development and Capabilities, 12 (1), 23 - 37. [https://doi.org/10.1080/ 19452829.2011.541731] 
PALOVIČOVÁ, Z. (2011): K pojmu sociálneho fungovania. Filozofia, 66 (9), 833 - 844.

PALOVIČOVÁ, Z. (2013): Senova teória spravodlivosti. Filozofia, 68 (4), 265 - 275.

RAWLS, J. (1995): Teorie spravedlnosti. Praha: Victoria Publishing.

RAWLS, J. (1997): Politický liberalizmus. Prešov: Slovacontact.

RAWLS, J. (2007): Spravodlivost' ako férovost'. Bratislava: Kalligram.

SIMPLICAN, C. S. (2016): Disavowals of Disability in Rawls' Theory of Justice and his Critics. In: Arneil, B., Hirschmann, J. N., (eds.): Disability and Political Theory. Cambridge: Cambridge University Press. [https://doi.org/10.1017/9781316694053]

URBAN, P. (2015): Enactivism and care ethics: merging perspectives. Filozofia, 70 (2), 119 - 129.

Napísanie tohto príspevku podporila Vedecká grantová agentúra MŠVVaŠ SR a SAV: VEGA 1/0132/17 ako súčast' projektu Právo na nezávislý život a začlenenie do spoločnosti osôb s postihnutím z pohl'adu sociálnej a politickej filozofie.

\section{Lukáš Siegel}

Katedra filozofie a aplikovanej filozofie

Filozofická fakulta UCM v Trnave

Námestie J. Herdu 2

91701 Trnava

Slovenská republika

e-mail: lukassiegel@gmail.com 